Document downloaded from:

http://hdl.handle.net/10251/164820

This paper must be cited as:

Lo-lacono-Ferreira, VG.; Viñoles-Cebolla, R.; Bastante-Ceca, M.; Capuz-Rizo, SF. (2020). Transport of Spanish fruit and vegetables in cardboard boxes: A carbon footprint analysis. Journal of Cleaner Production. 244:1-12. https://doi.org/10.1016/j.jclepro.2019.118784

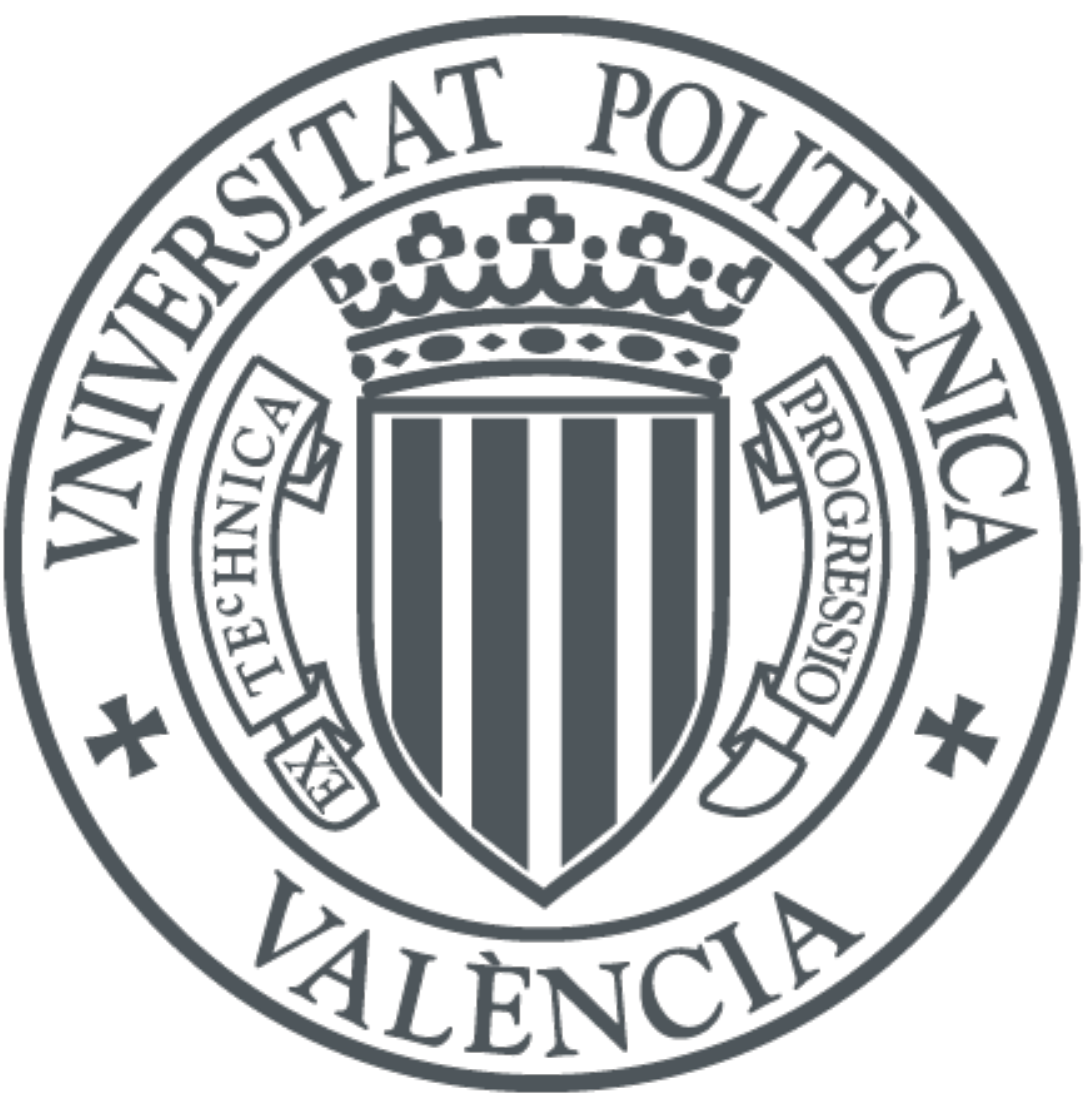

The final publication is available at

https://doi.org/10.1016/j.jclepro.2019.118784

Copyright Elsevier

Additional Information 


\title{
Transport of Spanish fruit and vegetables in cardboard boxes: A carbon footprint analysis
}

Vanesa G. Lo-Iacono-Ferreira ${ }^{\mathrm{a}}$; Rosario Viñoles-Cebolla ${ }^{\mathrm{b}}$; M José Bastante-Ceca ${ }^{\mathrm{c}}$; Salvador F. Capuz-

Rizo $^{\text {d }}$

${ }^{a}$ Universitat Politècnica de València, Pl. Ferrándiz y Carbonell, s/n 03801 Alicante, Spain.

valoia@upv.es [corresponding author]

${ }^{\mathrm{b}}$ Universitat Politècnica de València, Camino de Vera, s/n E-46022 Valencia, Spain. rovice@upvnet.upv.es

${ }^{c}$ Universitat Politècnica de València, Camino de Vera, s/n E-46022 Valencia, Spain. mabasce1@dpi.upv.es

${ }^{\mathrm{d}}$ Universitat Politècnica de València, Camino de Vera, s/n E-46022 Valencia, Spain. scapuz@dpi.upv.es

\begin{abstract}
The increase in international trade due to globalization is evident in southeast Spain, which has become the top exporter of fruit and vegetables. Countries within the European Union, such as Germany and France, emphasize the sustainability and environmental impacts of these products. Hence, a greater understanding of the environmental implications of transporting fruit and vegetables between their origin and their destination might improve the sustainability of this commercial activity. The concept of a carbon footprint is a recognized environmental indicator that can be used for life cycle analysis. Here, a rigorous carbon footprint assessment was developed to examine the impact of using cardboard box containers to store and transport 1,000 $\mathrm{t}$ of fruit and vegetable products by road from their origin in Almería, Spain, to a destination market. The assessment included the fabrication of the cardboard boxes, the service they provide while transporting the products to the distribution center of the destination, and the end-of-life of the boxes for the six main products grown in Almería. The results showed that storing and transporting 1,000 $\mathrm{t}$ of product by road emits between $58 \mathrm{t}$ and $130 \mathrm{t}$ of $\mathrm{CO}_{2} \mathrm{e}$ depending on the fruit or vegetable type and the destination market. The implications of the end-of-life scenarios with respect to the destination are also discussed. Furthermore, a sensitivity analysis was conducted for the transport distance. Lastly, biogenic $\mathrm{CO}_{2}$ production was also assessed according to standard carbon footprint assessment method.
\end{abstract}

\section{Highlights}

The carbon footprint of storage and transport of fruit and vegetables was assessed as an environmental indicator

End-of-life scenarios and transport distance were the key aspects affecting the environmental impact

Storing and transporting 1,000 $\mathrm{t}$ of fruits from Almería to main European markets emits between $58 \mathrm{t}$ and $130 \mathrm{t}$ of $\mathrm{CO}_{2} \mathrm{e}$

\section{Keywords}

Carbon footprint; cardboard boxes; fruit and vegetables; export; Life Cycle Assessment; ISO 14067

\author{
Abbreviations \\ ADEME Agence de l'Environnement et de la Maîtrise de l'Energie \\ CF Carbon Footprint \\ EEA European Environment Agency \\ FEFCO European Federation of Corrugated Board Manufacturers
}


FEPEX Spanish Federation of Associations of Exporting Producers of Fruits, Vegetables, Flowers and Live Plants

GHG Greenhouse gases

IEA International Energy Agency

IMO International Maritime Organization

INSEE Institut National de la Statistique et des Études Économiques

ISO International Organization for Standardization

LCA Life Cycle Assessment

MAIKWA Manufacturers of machines for cardboard production

\section{Introduction}

The comprehensive study of the environmental impact of a product or service requires life cycle assessment (LCA); however, given the amount of information required, the complexity of this analysis means that only a few environmental indicators are suitable for this type of assessment. Nevertheless, simplified environmental impact assessments based on a single indicator should only be carried out using a robust methodology (Finkbeiner, 2009; Neusebauer et al., 2015).

The 'carbon footprint' $(\mathrm{CF})$ is a widely known environmental impact indicator that quantifies greenhouse gas (GHG) emissions (Borsato et al., 2018; Parajuli et al., 2019; Soode et al., 2015). The environmental impacts of GHG emissions from packaging might be significant, accounting for between $7 \%$ and 54\% of the total emissions from fresh fruit and vegetable production, depending on the volume and the market (Del Borghi et al., 2014; Payen et al., 2015). Transport emissions, which account for approximately $43 \%$ of total emissions, might also be significant where transportation relies on non-renewable energy sources (Payen et al., 2015). Bortolini et al. (2016) proposed a methodology to optimize the distribution of fresh fruit and vegetables produced in Italy that considered costs, time, and the CF.

Parajuli et al. (2019) sought to evaluate environmental costs by conducting a literature review on LCA of fruit and vegetables and some of their derivatives. Their study highlighted the difficulties of making general recommendations as the results are highly dependent on market conditions. LCA has also been used in combination with other tools, such as artificial intelligence, to predict agricultural environmental impacts (Kaab et al., 2019), to optimize $\mathrm{CO}_{2}$ emissions in the production of certain fruits (NabaviPelesaraei et al., 2014), and to evaluate the energy efficiency of agricultural production (Kouchaki-Penchah et al., 2017). End-of-life phases have also been incorporated into these combined methods (Nabavi-Pelesaraei et al., 2017a; Nabavi-Pelesaraei et al., 2017b).

The production of fruit and vegetable derivatives (e.g., tomato puree and extra virgin olive oil) in the Italian market has also been studied (Manfredi \& Vignali, 2014, Pattara et al., 2016). Transport between factories and the retail centers have been shown to have the highest contribution to the overall GHG emissions (45\% to 50\%) often due to large transport distances. An environmental impact analysis of vegetables produced in Spain was conducted by Pérez Neira et al. (2018) who developed a CF and life cycle approach for tomatoes produced in heated greenhouses. However, their study was restricted to the transport of the products to the regional distribution center, meaning that the transport required for the products to reach the destination markets was disregarded. Other studies have analyzed different agricultural production techniques seeking to reduce GHG emissions including the use of "low-biomass vegetation areas" (Rivera-Méndez et al., 2017), moving production nearer to urban areas (Atallah et al., 2014; Pérez-Neira \& Grollmus-Venegas 2018; Sanyé-Mengual et al., 2012), eating seasonal foods (Röös \& 
Karlsson, 2013), and minimizing emissions during shopping trips (Soode et al., 2015). The influence of the energy efficiency of producers on GHG emissions has also been studied using data envelopment analysis (Nabavi-Pelesaraei, et al., 2014). Other influences on farming efficiency have also been studied including the effects of dam construction (Shabanzadeh-Khoshrody et al., 2016) and the size of orchards (Sabzevari et al., 2015).

The importance of packaging on the environmental impact of transporting fresh fruit and vegetables has already been established via various frameworks (Albrecht et al., 2013, Sim et al., 2007). Agence de l'Environnement et de la Maîtrise de l'Energie (ADEME, 2000) developed a LCA (which is not available in English) that focused on the transport of $1,000 \mathrm{~kg}$ of apples form a producer to a final distributor. The distribution phase was identified as the main contributor to the environmental impact of the cycle. Other products, such as mangos (Chonhenchob \& Singh, 2003), papaya (Chonhenchob \& Singh, 2005), and other citrus fruits (Leviet al., 2011) have also studied.

The containers used in the transport of fruit and vegetables have also been assessed from a life cycle perspective (Singh et al., 2006; Levi et al., 2011; Albrecht et al., 2013). These studies have compared different types of containers against a baseline defined for general purposes. For example, Albrecht et al. (2013) assumed an average of $15 \mathrm{~kg}$ of fruit or vegetables per box. However, as markets and products seem to be significant factors, fruit and vegetable producers and export companies in Spain might not possess sufficient information on environmental impacts to inform their packaging choices. Therefore, this study focused on the transport of selected fruits and vegetables in cardboard boxes from their production origin in the south of Spain to two reference markets, namely within France (with an average transport distance of 1,500 km) and Germany (with an average transport distance of 2,500 km). The following fruits and vegetables were selected:

- Cantaloupes

- Cucumbers

- Eggplants

- Peppers

- Tomatoes

- Zucchinis

\section{Methods}

Several organizations have developed regulations for the assessment of CFs including PAS 2050 of the GHG protocol (British Standard Institute, 2008) and ISO 14067 (ISO, 2018). For this study, ISO 14067 was chosen as the reference standard, which requires the following documentation:

- Emissions linked to the main life cycle phases

- Emissions from fossil carbon sources

- Emissions from biogenic carbon sources

It is important to note that biogenic $\mathrm{CO}_{2}$ was separately accounted for in this assessment, as specified by the standard. The assessment method was developed using SIMAPRO 8.0.1 Software (Pre-sustainability, 2019) and the Ecoinvent 3.01 database (Wernet et al., 2016). Figure 1 shows the overall methodology applied in this study, as based on ISO 14067. 


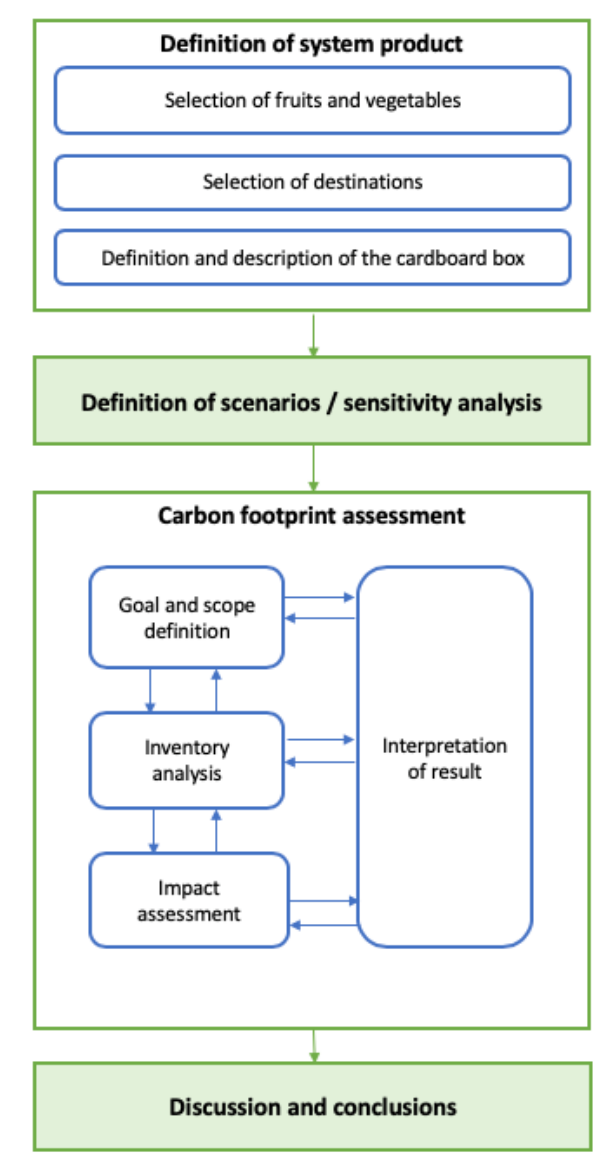

Fig. 1 Methodological framework.

\subsection{Definition of system product}

Export quotas were used as the basis for choosing the fruits and vegetables for this study. The total amount of each product was set based on the experience of the research group as applied in similar assessments, by considering approximately $25 \%$ of exports in monetary terms. The Spanish Federation of Associations of Exporting Producers of Fruits, Vegetables, Flowers and Live Plants (FEPEX) was chosen as a quality data source for this procedure. Table 1 shows the six fruits and vegetables produced in the Almería region of Spain with the highest exports in 2017. Together, these represented $25.78 \%$ of the total Spanish export in euros and $24 \%$ in terms of weight.

Table 1 Export data for fruit and vegetables (FEPEX, 2018)

\begin{tabular}{|l|r|r|}
\hline Product & Exportation (kiloton) & Exportation (EUR millions) \\
\hline Tomatoes & 810 & 1,003 \\
\hline Peppers & 687 & 954 \\
\hline Cucumbers & 627 & 566 \\
\hline Cantaloupes & 441 & 287 \\
\hline Zucchinis & 320 & 312 \\
\hline Eggplants & 144 & 152 \\
\hline Total products considered & $\mathbf{3 , 0 2 8}$ & $\mathbf{3 , 2 7 5}$ \\
Total exportation from & $\mathbf{1 2 , 6 1 7}$ & $\mathbf{1 2 , 7 0 4}$ \\
Spain & & \\
\hline
\end{tabular}


For the selected products, France and Germany are the major international markets, with a $51.43 \%$ share of annual Spanish fruit and vegetable exports by weight and $54.85 \%$ by economic value in 2017 (FEPEX, 2018). The transport distance considered in the assessment was a rounded-up value of the distance between Almería in the Andalusia Region in Spain and the capital city of each country, calculated by weighting the distance to the main cities according to their population (Table 2).

Table 2 Information for key Spanish fruit and vegetable markets

\begin{tabular}{|l|r|r|r|}
\hline Destination & Distance (km) & $\begin{array}{l}\text { Export share } \\
\text { (weight) 2017 }\end{array}$ & $\begin{array}{l}\text { Export share } \\
\text { (monetary) 2017 }\end{array}$ \\
\hline France & 1,500 & $23.66 \%$ & $23.95 \%$ \\
\hline Germany & 2,500 & $27.76 \%$ & $30.90 \%$ \\
\hline
\end{tabular}

The products were assumed to be transported from their origin to their destination in corrugated cardboard boxes with different dimensions depending on the product being transported. UNIQ boxes (Fig. 2) were selected as the most widely used on the market according to FEPEX.

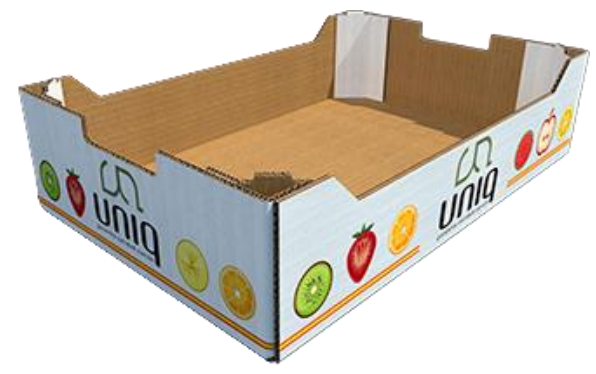

Fig 2 A UNIQ box (Group Unique, 2019).

The dimensions for each of the products considered in this study are shown in Table 3. Each product system was codified to simplify the analysis. Tomatoes are transported in two different types of boxes depending on the preference of the farmer, and as the use of each box size is equal, both were considered in this study. The dimensions of the boxes given in Table 3 are both for when they are in use (i.e., open) and when they are empty (i.e., folded).

Table 3. Product system description

\begin{tabular}{l|ccccc} 
& & \multicolumn{4}{c}{ Cardboard box dimensions } \\
\cline { 3 - 6 } Code & Vegetable or Fruit & $\begin{array}{c}\text { Open / in use } \\
\left(\mathbf{m m}^{\mathbf{3}}\right)\end{array}$ & $\begin{array}{c}\text { Folded / empty } \\
(\mathbf{m m})\end{array}$ & $\begin{array}{c}\text { Weight } \\
(\mathbf{k g})\end{array}$ & $\begin{array}{c}\text { Maximum } \\
\text { capacity } \\
(\mathbf{k g})\end{array}$ \\
\hline CA-400 & Cantaloupe & $400 \times 300 \times 145$ & 7.0 & 0.316 & 5 \\
CU-400 & Cucumber & $400 \times 300 \times 145$ & 7.0 & 0.316 & 5 \\
EP-400 & Eggplant & $400 \times 300 \times 145$ & 7.0 & 0.316 & 5 \\
PE-600 & Pepper & $600 \times 400 \times 200$ & 7.0 & 0.810 & 15 \\
TO-400 & Tomato & $400 \times 300 \times 145$ & 7.0 & 0.319 & 6 \\
TO-600 & Tomato & $600 \times 400 \times 90$ & 7.0 & 0.478 & 7 \\
ZU-400 & Zucchini & $400 \times 300 \times 145$ & 7.0 & 0.316 & 5 \\
\end{tabular}




\section{Definition of the scenarios and the sensitivity analysis}

Separate scenarios were configured for France and Germany (see Table 2). Therefore, two different scenarios were assessed for each product system. Distance and waste treatment procedures at the end-of-life were identified as sensitive parameters. For this reason, the Netherlands was included as a third country for the sensitivity analysis, with an average transport distance of 2,300 $\mathrm{km}$. The waste treatment procedures for each country are outlined in Section 2.4.3, which describes the end-of-life stage. The sensitivity analysis was developed for the product system that was most representative of the entire sample. Therefore, TO-600 (tomato) was selected as it had the highest proportion (approximately $30 \%$ ) of the traded amount among all of the products (Pérez Neira et al., 2018).

\subsection{Carbon footprint assessment}

\subsubsection{Goal and scope definition}

The goal of the assessment was to quantify the CF of cardboard boxes used to export refrigerated fruit and vegetables. The $\mathrm{CF}$ was assessed with the objective of visualizing the potential contribution of each of the product systems to climate change.

A functional unit was defined as the container system used to store and transport 1,000 $\mathrm{t}$ of product by road from its origin, located in Almería, southeast Spain, to the destination market. The function included the fabrication of the cardboard boxes, the service they provide in the transportation of the fruit or vegetable to the distribution center within the destination country, and the end-of-life treatment of the box. Table 4 describes the reference flows defined for each product system.

Table 4 Reference flows for the functional unit

\begin{tabular}{c|cccc}
\multicolumn{1}{c}{ Code } & Vegetable or Fruit & $\begin{array}{c}\text { Maximum } \\
\text { capacity }(\mathbf{k g})\end{array}$ & $\begin{array}{c}\text { Actual load } \\
(\mathbf{k g}) *\end{array}$ & $\begin{array}{c}\text { Number of } \\
\text { boxes }\end{array}$ \\
\hline CA-400 & Cantaloupe & 5 & 5 & 200,000 \\
CU-400 & Cucumber & 5 & 5 & 200,000 \\
EP-400 & Eggplant & 5 & 3 & 333,334 \\
PE-600 & Pepper & 15 & 10 & 100,000 \\
TO-400 & Tomato & 6 & 6 & 166,667 \\
TO-600 & Tomato & 7 & 7 & 142,858 \\
ZU-400 & Zucchini & 5 & 5 & 200,000 \\
*Data provided by the export companies & & &
\end{tabular}

System boundaries were defined as 'cradle-to-grave' boundaries while applying a closed loop for cardboard recycling following FEFCO (2015); FEFCO states that during the recycling process in both countries (Germany and France), a closed loop from cradle-to-grave can be assumed even when the recycling product does not feed into the same life cycle. Figure 3 illustrates the full life cycle that was assessed. Furthermore, each unit process was described. For this, the FEFCO database (2015) was used to build each unit process, flow-by-flow, based on the corresponding allocation. 


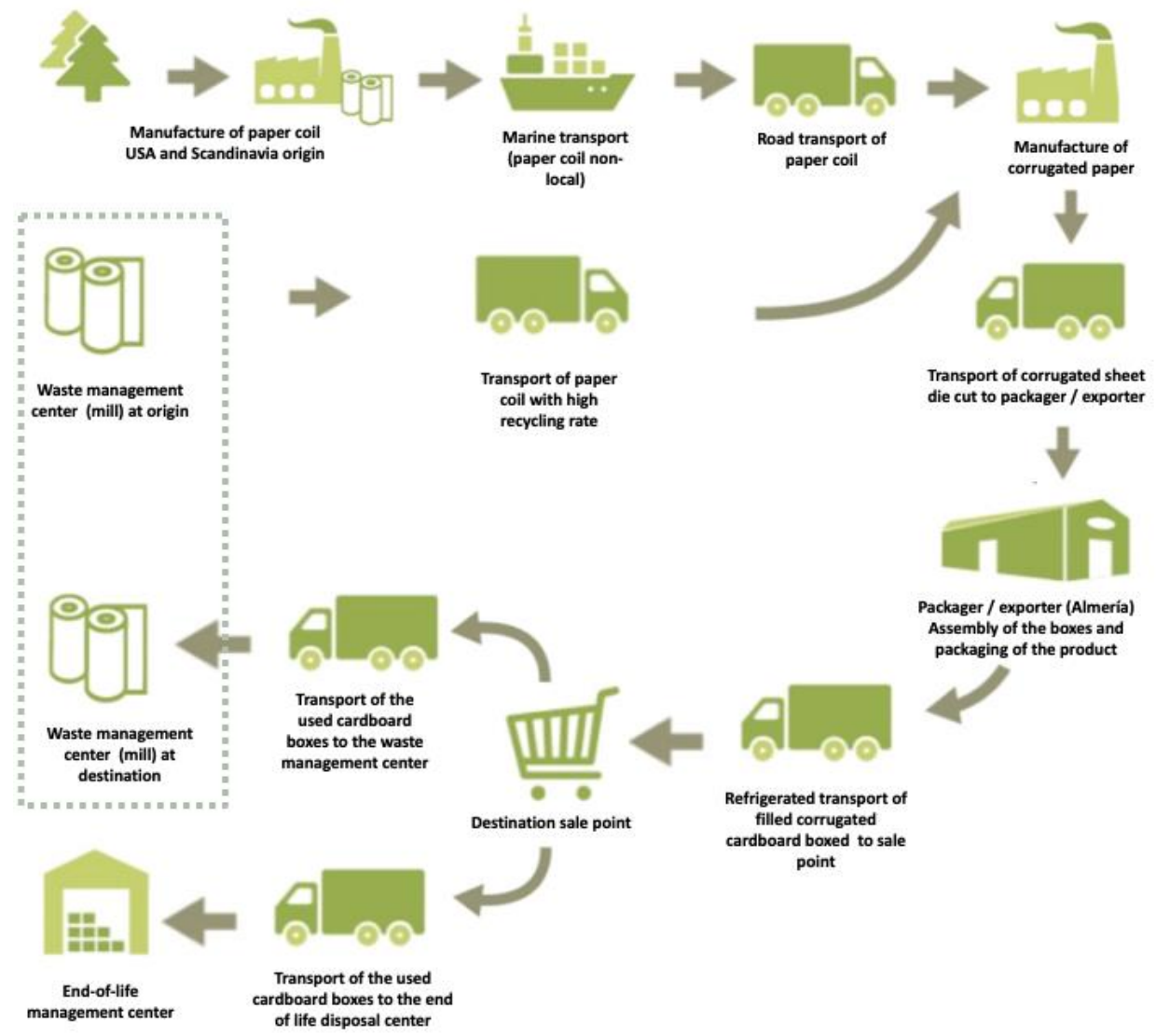

Fig. 3 Life cycle: Definition of system boundaries.

According to ISO 14044 (ISO, 2016), cut-off rules were applied to the inventory analysis by excluding those individual inputs that represented less than $5 \%$ of the total inputs of the system (on a mass or energy basis). The inputs affected by the cut-off were: pallets, low-density polyethylene film used for strapping and palletization of the boxes, sieving, cleaning treatments, and packing conducted at the entrance of the warehouse and during transport of the fruit and vegetables. Infrastructure was also excluded from the scope of this study.

Direct quantification was considered desirable to ensure data quality. Government organizations and recognized institutions, technical fact sheets, and the relevant literature were also considered as valid data sources when the desirable source was not viable. The quality index of data (DQR) suggested by the European Commission (2010) was chosen, which includes representativeness and completeness factors as well as uncertainty, as required by ISO 14067. DQR was assessed using Eq 1:

$$
D Q R=\frac{T e R+G R+T i R+C+P+M+X_{w} * 4}{i+4}
$$

where TeR is the technical representativeness; GR is the geographical representativeness; TiR is the temporal representativeness; $\mathrm{C}$ is the completeness; $\mathrm{P}$ is the precision/uncertainty; $\mathrm{M}$ is the methodology and consistency; $\mathrm{X}_{\mathrm{w}}$ is the most adverse level of all indicators; and $i$ is the total of all the indicators.

The indicators were assigned a number from 0 to 5, whereby: 0 represented "not applicable"; 1 accounted for a representativeness greater than 95\%; 2 indicated a representativeness of between $85 \%$ and $95 \% ; 3$ indicated a representativeness of 
between $75 \%$ and $85 \%$; 4 indicated a low representativeness of between $50 \%$ and $75 \%$; and 5 indicated a very low representativeness of less than $50 \%$.

Data with DQR values of 1.6 or less were classified as high quality (HQ); data with DQR values between 1.6 and 3.0 were classified as basic quality (BQ); and data with DQR values above 3.0 were considered as estimates (E). Table 5 shows the quality assessment of the inputs and flows that were used in the assessment. The analysis of each parameter was undertaken by the authors and was approved by an independent expert panel after critical review. The FEFCO, box manufacturers, and export companies were sources of the main parameters to ensure data quality. 
Table 5 Data quality analysis

\begin{tabular}{|c|c|c|c|c|c|c|c|c|c|}
\hline Input / flow & TeR & GR & TiR & C & $\mathbf{P}$ & M & Source & DQR & \\
\hline $\begin{array}{l}\text { Dimensions, } \\
\text { maximum capacities, } \\
\text { weight, and box } \\
\text { composition }\end{array}$ & 0 & 1 & 1 & 2 & 2 & 2 & $\begin{array}{l}\text { Box } \\
\text { manufacturers }\end{array}$ & 1.78 & BQ \\
\hline $\begin{array}{l}\text { Environmental data } \\
\text { of raw materials for } \\
\text { box manufacture }\end{array}$ & 2 & 1 & 1 & 1 & 2 & 1 & FEFCO, 2015 & 1.60 & HQ \\
\hline $\begin{array}{l}\text { Actual load of the } \\
\text { boxes for each fruit } \\
\text { or vegetable }\end{array}$ & 0 & 2 & 2 & 2 & 2 & 1 & $\begin{array}{l}\text { Export } \\
\text { companies }\end{array}$ & 1.89 & BQ \\
\hline Internal transport & 3 & 3 & 2 & 2 & 3 & 2 & $\begin{array}{l}\text { Export } \\
\text { companies }\end{array}$ & 2.70 & BQ \\
\hline $\begin{array}{l}\text { Electrical supply } \\
\text { model }\end{array}$ & 0 & 2 & 2 & 1 & 2 & 2 & $\begin{array}{l}\text { OECD/IEA, } \\
2015\end{array}$ & 1.89 & BQ \\
\hline $\begin{array}{l}\text { Fuel for internal } \\
\text { transport }\end{array}$ & 0 & 3 & 3 & 2 & 2 & 2 & $\begin{array}{l}\text { Ecoinvent } \\
3.01 \text { database }\end{array}$ & 2.67 & BQ \\
\hline $\begin{array}{l}\text { Manufacturing and } \\
\text { die-cut process of } \\
\text { cardboard }\end{array}$ & 2 & 1 & 1 & 2 & 2 & 2 & $\begin{array}{l}\text { FEFCO, } \\
2015 ; \\
\text { MAIKWA, } \\
2017\end{array}$ & 1.8 & BQ \\
\hline $\begin{array}{l}\text { Trucks and ships for } \\
\text { raw materials and } \\
\text { cardboard box } \\
\text { transport }\end{array}$ & 2 & 2 & 2 & 2 & 2 & 2 & $\begin{array}{l}\text { Ecoinvent } \\
3.01 \text { database }\end{array}$ & 2 & BQ \\
\hline $\begin{array}{l}\text { Emission factors for } \\
\text { the modeling of road } \\
\text { transport }\end{array}$ & 0 & 2 & 1 & 1 & 2 & 2 & $\begin{array}{l}\text { EMEP/EEA, } \\
2014\end{array}$ & 1.78 & BQ \\
\hline $\begin{array}{l}\text { Emission factors for } \\
\text { the modeling of } \\
\text { maritime transport }\end{array}$ & 0 & 2 & 1 & 1 & 2 & 2 & IMO & 1,78 & BQ \\
\hline $\begin{array}{l}\text { Distance to the } \\
\text { destination market }\end{array}$ & 0 & 2 & 1 & 2 & 3 & 2 & $\begin{array}{l}\text { Statistics } \\
\text { Netherlands } \\
\text { May 2016, } \\
\text { INSEE, 2015 } \\
\text { Federal } \\
\text { Statistical } \\
\text { Office, 2013 } \\
\text { Vía Michelín, } \\
2017\end{array}$ & 2.44 & BQ \\
\hline $\begin{array}{l}\text { Distribution of the } \\
\text { waste management } \\
\text { treatments of plastic } \\
\text { packaging }\end{array}$ & 0 & 1 & 1 & 1 & 2 & 2 & $\begin{array}{l}\text { Eurostat, } \\
2017\end{array}$ & 1.67 & BQ \\
\hline End-of-life treatment & 3 & 3 & 3 & 3 & 3 & 3 & $\begin{array}{l}\text { Ecoinvent } \\
3.01\end{array}$ & 3 & BQ \\
\hline
\end{tabular}

The oldest data sources applied in the assessment were from 2014 and the most recent data were from 2017. This period was considered the data time limit for which the results of the assessment are most meaningful.

The limitations of the study were defined by the underlying assumptions and some additional considerations (Fig. 4):

- Transport of raw materials: Paper rolls were transported to the box manufacturer in non-refrigerated trucks with a $40 \mathrm{t}$ maximum authorized weight and a tare of $16 \mathrm{t}$. 
- Transport from the box manufacturer to the producer/packer was via nonrefrigerated trucks with a $40 \mathrm{t}$ maximum authorized weight and a tare of $16 \mathrm{t}$.

- Transport of the loaded cardboard boxed from the producer/packer to the destination market was via refrigerated trucks with a $40 \mathrm{t}$ maximum authorized weight and a tare of $16 \mathrm{t}$.

- Transport of the used cardboard boxes to the waste management centers was via non-refrigerated trucks with a $16 \mathrm{t}$ maximum authorized weight and a tare of 6.5 t.

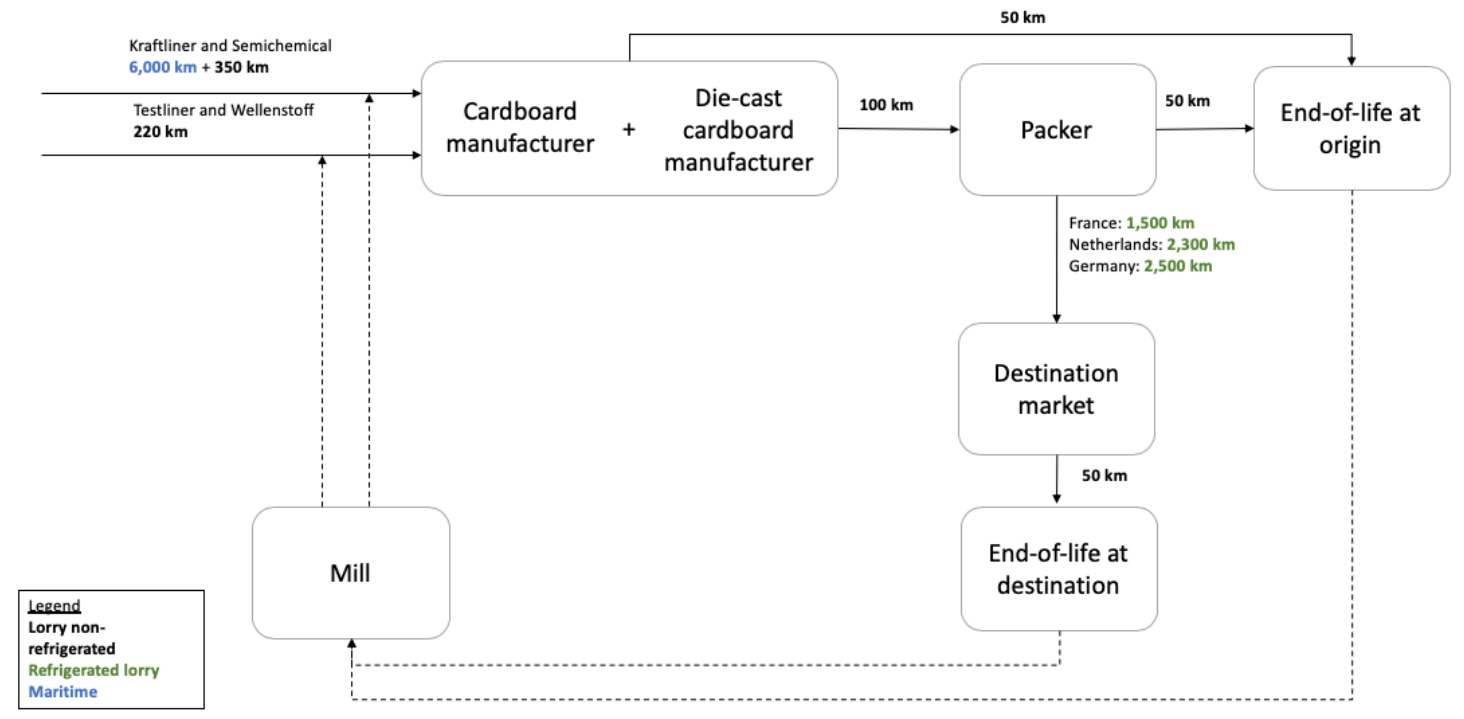

Fig. 4 Transport stages, distances, and types of trucks.

The fuel consumption for each type of truck is shown in Table 6 with respect to the load being transported. It should be noted that the consumption of compressors in refrigerated trucks was also related to the load being transported.

Table 6 Information for transport by truck

\begin{tabular}{|l|l|c|c|}
\hline Type of truck & $\begin{array}{l}\text { Ecoinvent 3.01 } \\
\text { database reference }\end{array}$ & Load transported (t) & $\begin{array}{l}\text { Fuel consumption } \\
(\mathbf{l} / \mathbf{1 0 0} \mathbf{~ k m})\end{array}$ \\
\hline $\begin{array}{l}\text { Non-refrigerated truck, } \\
\mathbf{1 6} \mathbf{t}\end{array}$ & $\begin{array}{l}\text { Transport, freight, } \\
\text { lorry 7.5-16 metric } \\
\text { ton, EURO5 RER }\end{array}$ & 9.5 & 24 \\
\hline \multirow{2}{*}{$\begin{array}{l}\text { Non-refrigerated truck, } \\
\mathbf{4 0} \mathbf{t}\end{array}$} & $\begin{array}{l}\text { Transport, freight, } \\
\text { lorry >32 metric ton, }\end{array}$ & $23-20$ & 33 \\
\hline & EURO5 RER & $19-15$ & 32 \\
\hline \multirow{2}{*}{ Refrigerated truck, 40 t } & $\begin{array}{l}\text { Transport, freight, } \\
\text { lorry >32 metric ton, }\end{array}$ & $14-10$ & 31 \\
\hline & EURO5 RER & $9-8$ & 30 \\
\cline { 3 - 4 } & & $23-20$ & 36 \\
\hline
\end{tabular}

Diesel and electric forklifts were considered for the internal transport assuming a proportional use of $33 \%$ and $67 \%$, respectively. The forklifts had a load of $1,500 \mathrm{~kg}$ and a movement time of $60 \mathrm{~s}$. The power consumption for diesel forklifts working at full load was $2.3 \mathrm{l} / \mathrm{h}$ (Wernet et al., 2016) and for electrical forklifts was $4.1 \mathrm{kWh} / \mathrm{h}$ (IEA, 2015). 
Additional assumptions were made regarding the end-of-life of the cardboard boxes. Specifically, it was assumed that once used, all boxes were managed at the waste treatment plants of the destination country with the exception of $0.1 \%$ of the boxes, which were assumed to break during their assembly at the packing site (the breakage rate). In the case of broken boxes, these were assumed to be managed at the waste treatment plant of the exporting country.

Since the recycling process was allocated proportionally, the associated GHG emissions were shared among more than one product system (ISO, 2018). Following ISO 14044 (ISO, 2016), the allocation of shared unit processes was based on a closed cycle when considering the raw materials. Closed cycles are applicable when the recycled materials are recovered during the end-of-life stage and reused in the same system. In this case, the allocation was avoided as the recovered fibers replaced the use of virgin fibers. The allocation of other emissions linked to the flows of each unit process was defined according to the FEFCO (2015) database.

The emissions produced during the recycling process were accounted for under the endof-life stage, considered as credit on the manufacturing stage of the cardboard boxes. GHG emissions from fossil and biogenic $\mathrm{CO}_{2}$ were also included in the assessment, being accounted for separately, according to ISO 14067:2018 (ISO, 2018).

The limitations of the study therefore affected the quantification of the $\mathrm{CF}$ and are included in the results dissemination (ISO, 2018). The two main limitations of this study were the focus on climate change as the only impact category (as defined by the $\mathrm{CF}$ ) and the inherent limitations of the methodology described.

This study was subjected to an independent critical review following the suggestions of ISO 14044. The review was undertaken by three external, internationally recognized experts who developed a detailed report that acknowledged the adequate development of the study and the correct application of the regulations. This article summarized the information once the critical reviewers had validated the study and its results.

\subsection{Inventory analysis}

\subsubsection{Cardboard box manufacturing}

Cardboard box manufacturing includes the manufacture of paper coils, the transport of the coils (via marine and road routes), and the manufacture and die-cutting of the corrugated paper. This manufacturing process includes white coils and coils with a high recycling rate (Fig. 3). Cardboard box manufacturing requires four types of paper: (1) Kraftliner, (2) semi-chemical fluting, (3) Testliner, and (4) Wellenstoff. The environmental data for these materials was obtained from the European Database for Corrugated Board Life Cycle Studies (FEFCO, 2015), which includes raw materials, additives, the energy required, emissions, water waste, waste, and associated transport. The paper rolls were transported to the manufacturing sites of the cardboard boxes. Krafliner paper rolls with $0 \%$ and $20 \%$ recycled fibers required trans-oceanic transport $(6,000 \mathrm{~km})$ and additional road transport via a $40 \mathrm{t}$ truck $(350 \mathrm{~km})$. Maritime transport was modeled using emission factors provided by the International Maritime Organization (IMO, 2015). Testliner and Wellnstoff paper rolls with $100 \%$ recycled fibers were transported $220 \mathrm{~km}$ with a $40 \mathrm{t}$ truck by road. The composition of each UNIQ cardboard box for each product system is described in Table 7. The unit process is shown in Fig. 5. 
Table 7. Composition of cardboard boxes

\begin{tabular}{|c|c|c|c|c|c|}
\hline $\begin{array}{l}\text { Product } \\
\text { system }\end{array}$ & Layer 1 (external) & Layer 2 & Layer 3 & Layer 4 & $\begin{array}{l}\text { Layer } 5 \\
\text { (internal) }\end{array}$ \\
\hline TO-600 & $\begin{array}{l}\text { Testliner, } 100 \% \\
\text { recycled fibers } \\
\text { Paper grade: } 195 \\
\mathrm{~g} / \mathrm{m}^{2}\end{array}$ & $\begin{array}{l}\text { Wellenstoff, } \\
100 \% \text { recycled } \\
\text { fibers } \\
\text { Paper grade: } \\
170 \mathrm{~g} / \mathrm{m}^{2} \\
\text { Channel B, } \\
\text { coef. } 1.33\end{array}$ & $\begin{array}{l}\text { Wellenstoff, } \\
100 \% \text { recycled } \\
\text { fibers } \\
\text { Paper grade: } \\
170 \mathrm{~g} / \mathrm{m}^{2}\end{array}$ & $\begin{array}{l}\text { Wellenstoff, } \\
100 \% \text { recycled } \\
\text { fibers } \\
\text { Paper grade: } \\
190 \mathrm{~g} / \mathrm{m}^{2} \\
\text { Channel C, } \\
\text { coef. } 1.43\end{array}$ & $\begin{array}{l}\text { Testliner, } \\
100 \% \text { recycled } \\
\text { fibers } \\
\text { Paper grade: } \\
250 \mathrm{~g} / \mathrm{m}^{2}\end{array}$ \\
\hline TO-400 & $\begin{array}{l}\text { Kraftliner, } 20 \% \\
\text { recycled fibers } \\
\text { Paper grade: } 135 \mathrm{~g} / \\
\mathrm{m}^{2}\end{array}$ & $\begin{array}{l}\text { Wellenstoff, } \\
100 \% \text { recycled } \\
\text { fibers } \\
\text { Paper grade: } \\
150 \mathrm{~g} / \mathrm{m}^{2} \\
\text { Channel B, } \\
\text { coef. } 1.33\end{array}$ & $\begin{array}{l}\text { Wellenstoff, } \\
100 \% \text { recycled } \\
\text { fibers } \\
\text { Paper grade: } \\
170 \mathrm{~g} / \mathrm{m}^{2}\end{array}$ & $\begin{array}{l}\text { Wellenstoff, } \\
100 \% \text { recycled } \\
\text { fibers } \\
\text { Paper grade: } \\
190 \mathrm{~g} / \mathrm{m}^{2} \\
\text { Channel C, } \\
\text { Coef. } 1.43\end{array}$ & $\begin{array}{l}\text { Kraftliner, } \\
20 \% \text { recycled } \\
\text { fibers } \\
\text { Paper grade: } \\
170 \mathrm{~g} / \mathrm{m}^{2}\end{array}$ \\
\hline $\begin{array}{l}\text { CA-400 } \\
\text { CU-400 } \\
\text { EP-400 } \\
\text { ZU-400 }\end{array}$ & $\begin{array}{l}\text { Kraftliner, } 20 \% \\
\text { recycled fibers } \\
\text { Paper grade: } 135 \mathrm{~g} / \\
\mathrm{m}^{2}\end{array}$ & $\begin{array}{l}\text { Wellenstoff, } \\
100 \% \text { recycled } \\
\text { fibers } \\
\text { Paper grade: } \\
150 \mathrm{~g} / \mathrm{m}^{2} \\
\text { Channel B, } \\
\text { coef. } 1.33\end{array}$ & $\begin{array}{l}\text { Wellenstoff, } \\
100 \% \text { recycled } \\
\text { fibers } \\
\text { Paper grade: } \\
120 \mathrm{~g} / \mathrm{m}^{2}\end{array}$ & $\begin{array}{l}\text { Wellenstoff, } \\
100 \% \text { recycled } \\
\text { fibers } \\
\text { Paper grade: } \\
150 \mathrm{~g} / \mathrm{m}^{2} \\
\text { Channel C, } \\
\text { Coef. } 1.43\end{array}$ & $\begin{array}{l}\text { Kraftliner, } \\
20 \% \text { recycled } \\
\text { fibers } \\
\text { Paper grade: } \\
170 \mathrm{~g} / \mathrm{m}^{2}\end{array}$ \\
\hline PE-600 & $\begin{array}{l}\text { Testliner, } 100 \% \\
\text { recycled fibers } \\
\text { Paper grade: } 170 \\
\mathrm{~g} / \mathrm{m}^{2}\end{array}$ & $\begin{array}{l}\text { Wellenstoff, } \\
100 \% \text { recycled } \\
\text { fibers } \\
\text { Paper grade: } \\
150 \mathrm{~g} / \mathrm{m}^{2} \\
\text { Channel E, } \\
\text { coef. } 1.33\end{array}$ & $\begin{array}{l}\text { Wellenstoff, } \\
100 \% \text { recycled } \\
\text { fibers } \\
\text { Paper grade: } \\
120 \mathrm{~g} / \mathrm{m}^{2}\end{array}$ & $\begin{array}{l}\text { Wellenstoff, } \\
100 \% \text { recycled } \\
\text { fibers } \\
\text { Paper grade: } \\
150 \mathrm{~g} / \mathrm{m}^{2} \\
\text { Channel B, } \\
\text { Coef. } 1.43\end{array}$ & $\begin{array}{l}\text { Testliner, } \\
100 \% \text { recycled } \\
\text { fibers } \\
\text { Paper grade: } \\
170 \mathrm{~g} / \mathrm{m}^{2}\end{array}$ \\
\hline
\end{tabular}

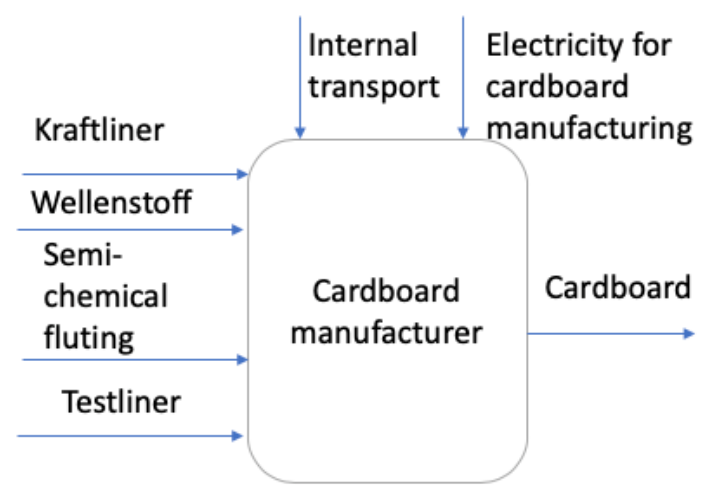

Fig. 5. Cardboard manufacturing process (see Fig. 3 for further details).

The die-cutting and manufacturing of the cardboard boxes were considered with a $10 \%$ loss of material due to the cutting of the cardboard sheets. For this, FEFCO (2015) and MAIKWA (2017) provided the required data. The unit process is shown in Fig. 6. 


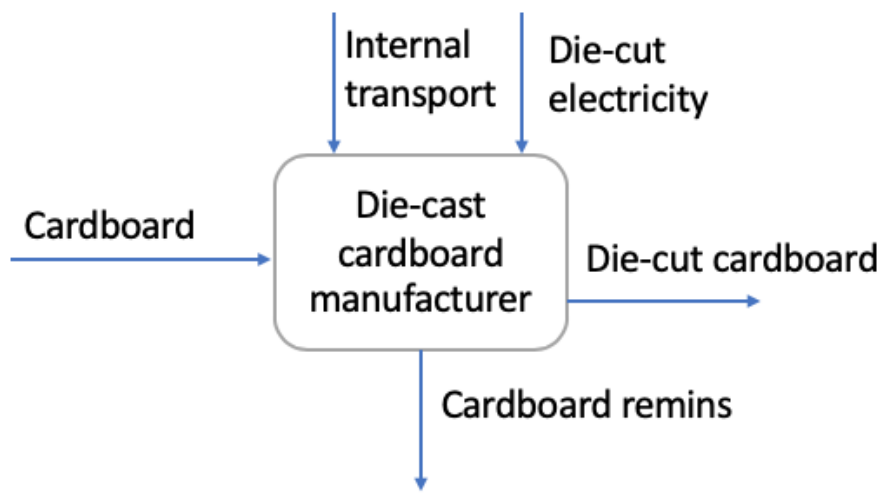

Fig. 6. Cardboard box manufacturing process and die-casting (see Fig. 3 for further details).

Table 8 shows the information relating to the transport of the cardboard boxes to the producer/packer of the vegetables and fruits. The average transport distance was $100 \mathrm{~km}$ via a $40 \mathrm{t}$ non-refrigerated truck. The percentage of cardboard boxes that were damaged during the manufacturing was managed as waste in Spain. The unit process scheme is shown in Fig. 7.

Table 8. Transport of cardboard boxes to the packer

\begin{tabular}{c|cccc}
$\begin{array}{c}\text { Product } \\
\text { system }\end{array}$ & $\begin{array}{c}\text { Cardboard sheets } \\
\text { per truck }\end{array}$ & $\begin{array}{c}\text { Sheets required } \\
\text { to transport } \\
\text { 1,000 t of fruit } \\
\text { or vegetables }\end{array}$ & $\begin{array}{c}\text { Percentage } \\
\text { of losses }\end{array}$ & $\begin{array}{c}\text { Total sheets } \\
\text { required per } \\
\text { functional } \\
\text { unit }\end{array}$ \\
\hline CA-400 & 29,500 & 200,000 & $0.1 \%$ & 200,200 \\
CU-400 & 29,500 & 200,000 & $0.1 \%$ & 200,200 \\
EP-400 & 29,500 & 333,334 & $0.1 \%$ & 333,667 \\
PE-600 & 14,750 & 100,000 & $0.1 \%$ & 100,100 \\
TO-400 & 29,500 & 166,667 & $0.1 \%$ & 166,834 \\
TO-600 & 14,750 & 142,858 & $0.1 \%$ & 143,001 \\
ZU-400 & 29,500 & 200,000 & $0.1 \%$ & 200,200 \\
\end{tabular}

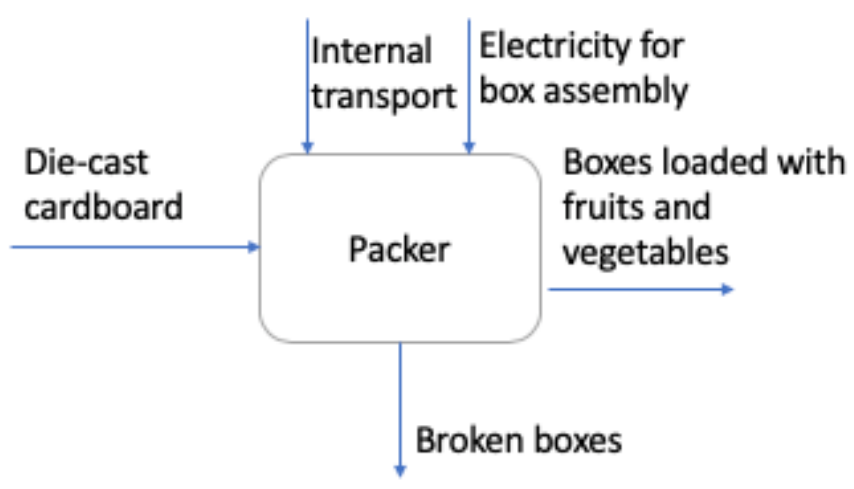

Fig 7. Packing process (see Fig. 3 for further details).

Table 9 shows the weights considered for the internal transport inside the packing facilities. 
Table 9. Weight for internal transport consideration

\begin{tabular}{|c|cc}
$\begin{array}{c}\text { Product } \\
\text { system }\end{array}$ & Weight of cardboard sheet $(\mathbf{k g})$ & $\begin{array}{c}\text { Weight of die-cut } \\
\text { cardboard sheet }(\mathbf{k g})\end{array}$ \\
\hline CA-400 & 0.35111 & 0.316 \\
CU-400 & 0.35111 & 0.316 \\
EP-400 & 0.35111 & 0.316 \\
PE-600 & 0.70222 & 0.632 \\
TO-400 & 0.35444 & 0.319 \\
TO-600 & 0.53111 & 0.478 \\
ZU-400 & 0.35111 & 0.361 \\
\end{tabular}

\subsubsection{Transport of loaded boxes}

Once the cardboard boxes were loaded with the corresponding fruit or vegetables they were transported to the destination market in $40 \mathrm{t}$ refrigerated trucks. Table 10 shows the information related to the capacity of this transport pathway.

Table 10 Transport of cardboard boxes loaded with fruit and vegetables.

\begin{tabular}{|c|cccccccc}
$\begin{array}{c}\text { Product } \\
\text { system }\end{array}$ & $\begin{array}{c}\text { Rows of } \\
\text { boxes by } \\
\text { pallet }\end{array}$ & $\begin{array}{c}\text { Boxes } \\
\text { by row }\end{array}$ & $\begin{array}{c}\text { Pallets } \\
\text { per } \\
\text { truck }\end{array}$ & $\begin{array}{c}\text { Actual } \\
\text { load } \\
\text { per box } \\
\text { (kg) }\end{array}$ & $\begin{array}{c}\text { Boxes } \\
\text { by } \\
\text { truck }\end{array}$ & $\begin{array}{c}\text { Boxes to } \\
\text { transport } \\
\text { per } \\
\text { functional } \\
\text { unit }\end{array}$ & $\begin{array}{c}\text { Total } \\
\text { load to } \\
\text { transport } \\
\text { per truck } \\
\text { (t) }\end{array}$ & $\begin{array}{c}\text { Number of } \\
\text { trips to } \\
\text { transport } \\
\mathbf{1 , 0 0 0} \text { t } \\
\text { (functional } \\
\text { unit) }\end{array}$ \\
\hline CA-400 & 14 & 8 & 33 & 5 & 3,696 & 200,000 & 19.65 & 54.11 \\
\hline CU-400 & 14 & 8 & 33 & 5 & 3,696 & 200,000 & 19.65 & 54.11 \\
\hline EP-400 & 14 & 8 & 33 & 3 & 3,696 & 222,224 & 12.26 & 90.19 \\
\hline PE-600 & 10 & 4 & 33 & 10 & 1,320 & 100,000 & 14.03 & 75.76 \\
TO-400 & 14 & 8 & 33 & 6 & 3,696 & 166,667 & 23.36 & 45.09 \\
\hline TO-600 & 22 & 4 & 33 & 7 & 2,904 & 142,858 & 21.72 & 49.19 \\
\hline ZU-400 & 14 & 8 & 33 & 5 & 3,696 & 200,000 & 19.65 & 54.11 \\
\hline
\end{tabular}

According to the Spanish law (Royal Decree 888/1988

https://www.boe.es/eli/es/rd/1988/07/29/888), these types of boxes can only be used once. Therefore, no cleaning or other related processes were involved. Thus, a cardboard box ends its service life once the transport is complete.

\subsubsection{End-of-life of the boxes}

Two processes were considered at this stage: (1) transport to the waste treatment center and (2) the waste treatment processing (Fig. 8). After use, all boxes were managed at the destination. However, a small percentage $(0.1 \%)$ usually break during the assembly, which was managed in Spain.

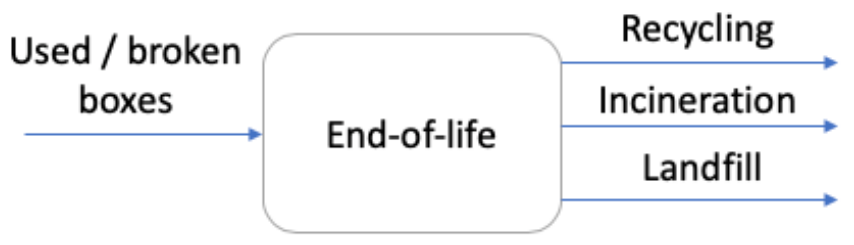

Fig. 8 Waste treatment process (see Fig. 3 for further details). 
Table 11 shows the data collected for all of the end-of-life processes for each country involved. Eurostat (2017) was chosen as the most reliable data source; although information is available for 2014, the database used in this study was for July 2017.

Table11 Distribution of processes applied for cardboard waste treatment by country (Eurostat, 2017)

\begin{tabular}{|c|c|c|c|c|c|}
\hline Country & $\begin{array}{l}\text { Incineration } \\
\text { / energy } \\
\text { recovery }\end{array}$ & $\begin{array}{l}\text { Recovery, } \\
\text { except } \\
\text { energy } \\
\text { recovery }\end{array}$ & $\begin{array}{l}\text { Incineration } \\
\text { with energy } \\
\text { recovery at } \\
\text { waste } \\
\text { incinerators }\end{array}$ & $\begin{array}{l}\text { Material } \\
\text { recycling }\end{array}$ & $\begin{array}{l}\text { Other } \\
\text { recycling } \\
\text { including } \\
\text { compost }\end{array}$ \\
\hline FRANCE & $0.00 \%$ & $0.00 \%$ & $5.15 \%$ & $94.43 \%$ & $0.42 \%$ \\
\hline GERMANY & $12.28 \%$ & $0.00 \%$ & $0.03 \%$ & $87.33 \%$ & $0.36 \%$ \\
\hline NETHERLANDS ${ }^{(1)}$ & $0.00 \%$ & $0.00 \%$ & $24.59 \%$ & $75.41 \%$ & $0.00 \%$ \\
\hline SPAIN & $0.00 \%$ & $0.00 \%$ & $5.38 \%$ & $94.62 \%$ & $0.00 \%$ \\
\hline
\end{tabular}

(1) Only for the sensitivity analysis

The end-of-life stage closes the life cycle loop with the unit process of recycling cardboard, as previously described (Fig. 9).

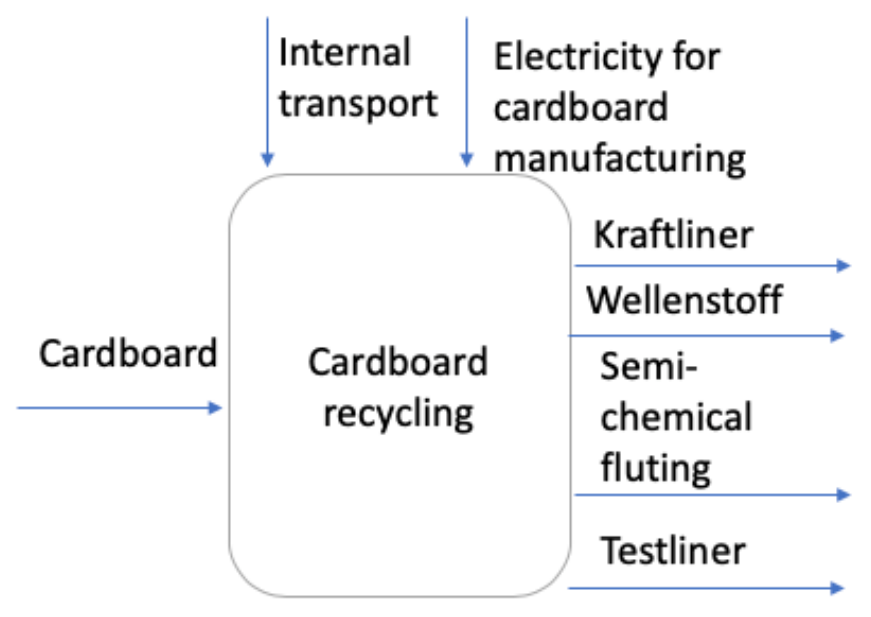

Fig. 9 Cardboard recycling process (see Fig. 3 for further details).

\subsection{Impact assessment}

The impact assessment was conducted following the methodology described in Section 2 using SimaPro software (Pre-sustainability, 2019). Version 1.02 of Intergovernmental Panel on Climate Change (IPCC) 2007 GWP 100a method was chosen for the assessment. For this, the characterization factors were based on the IPCC $4^{\text {th }}$ assessment report (Foster et al., 2007).

The results of the impact assessment are shown for each product system in Table 12. The assessment compared both destinations, considered a $0.1 \%$ damage rate, and the different box dimensions as previously described. 
Table 12 CF results by product system

\begin{tabular}{|c|c|c|c|c|c|c|c|c|}
\hline \multirow[t]{2}{*}{ Destination: } & \multicolumn{4}{|c|}{ France $(1,500$ km) } & \multicolumn{4}{|c|}{ Germany $(2,500$ km) } \\
\hline & \multicolumn{8}{|c|}{ Carbon Footprint $\left(\mathrm{tCO}_{2} \mathrm{e}\right)$} \\
\hline $\begin{array}{l}\text { Product } \\
\text { system }\end{array}$ & 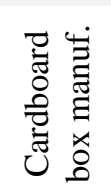 & 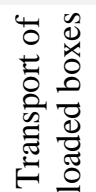 & 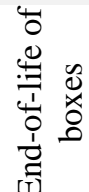 & $\stackrel{\bar{\pi}}{0}$ &  & 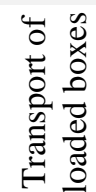 & 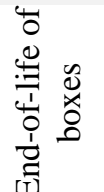 & $\stackrel{\bar{\pi}}{0}$ \\
\hline CA-400 & 61.87 & 6.26 & 1.42 & 69.55 & 61.87 & 10.43 & 2.37 & 74.67 \\
\hline CU-400 & 61.87 & 6.26 & 1.42 & 69.55 & 61.87 & 10.43 & 2.37 & 74.67 \\
\hline EP-400 & 103.12 & 13.78 & 2.37 & 119.27 & 103.12 & 22.97 & 3.95 & 130.04 \\
\hline PE-600 & 64.39 & 8.27 & 1.42 & 74.09 & 64.39 & 13.78 & 2.37 & 80.54 \\
\hline TO-400 & 52.24 & 4.31 & 1.20 & $\mathbf{5 7 . 7 5}$ & 52.24 & 7.18 & 1.99 & 61.41 \\
\hline TO-600 & 69.77 & 5.53 & 1.53 & 76.84 & 69.77 & 9.22 & 2.56 & 81.55 \\
\hline ZU-400 & 61.87 & 6.26 & 1.42 & 69.55 & 61.87 & 10.43 & 2.37 & $\mathbf{7 4 . 6 7}$ \\
\hline
\end{tabular}

\section{Results and Discussion}

It is evident that the physical properties of each fruit and vegetable, such as their dimensions and weight, have a direct influence on the container system used to store and transport 1,000 $\mathrm{t}$ of product by road from its origin to the destination market. Figure 10 and Fig. 11 show a comparison of the CF of each product system for the same destination.

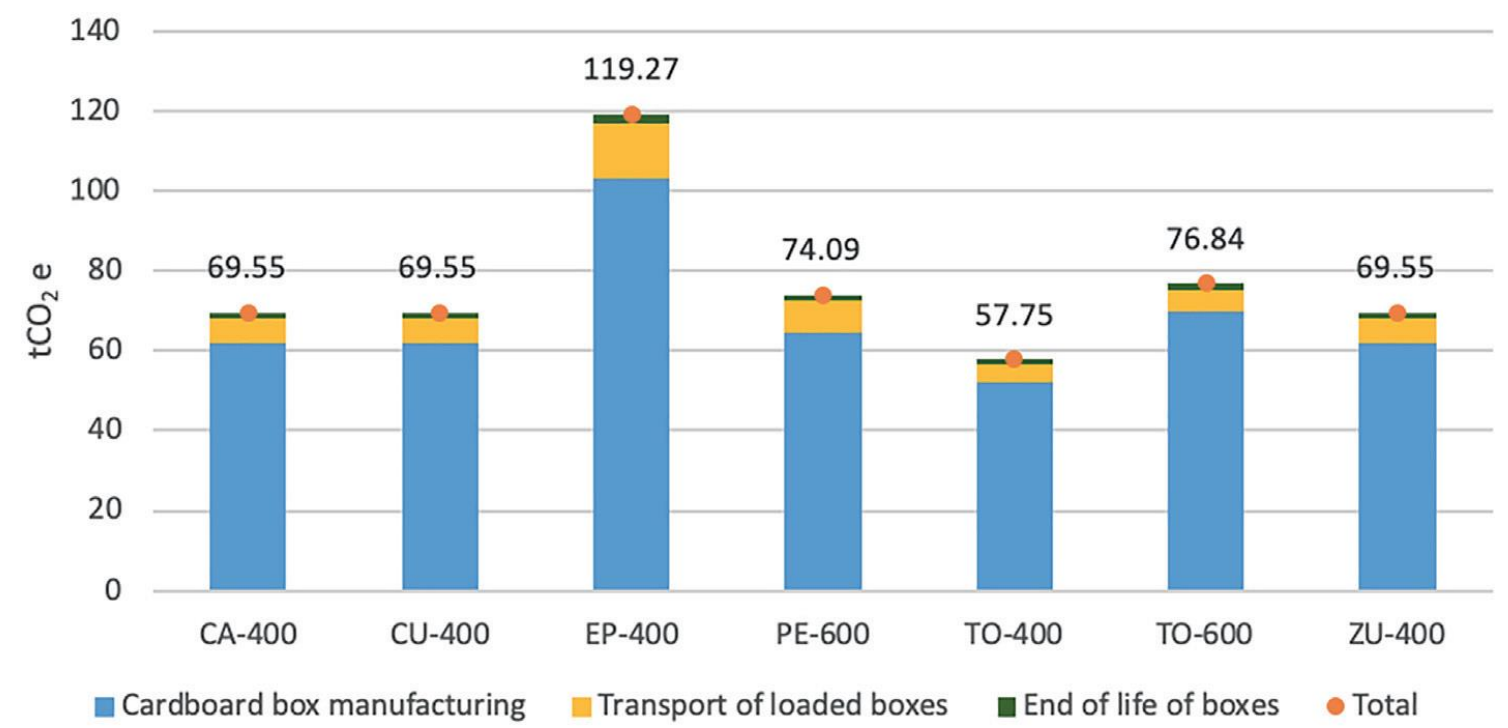

Fig. $10 \mathrm{CF}$ results for all product systems destined for France $(1,500 \mathrm{~km})$ 




Fig. $11 \mathrm{CF}$ results for all product systems destined for Germany $(2,500 \mathrm{~km})$

The results highlight that, for both the destination markets, a higher impact for eggplants, at 56\% over the average impact for France and increasing up to 58\% over the average impact for Germany. A difference of more than $60 \mathrm{tCO}_{2} \mathrm{e}$ between eggplants, which had the highest impact, and tomatoes, which had the lowest impact, when transported in $400 \mathrm{~mm}$ boxes to both markets. Cantaloupes, cucumbers, and zucchinis had the same level of impact for both markets as the characteristics of their transport and packaging were the same.

The key parameter in this comparison and the main difference between each product system was the actual load of the cardboard boxes (see Table 4). Eggplants and peppers had a $0.40 \%$ and $0.33 \%$ difference between the maximum capacity and the actual load, respectively. However, as peppers were transported in larger boxes $(600 \times 400 \times 200$ $\mathrm{mm}^{3}$ ) compared to eggplants, 233,334 extra boxes were required to transport 1,000 t of product, reducing the CF of peppers in both scenarios.

The results showed that storing and transporting 1,000 $\mathrm{t}$ of product by road from Almería to the destination markets emits an estimated $58 \mathrm{t}$ to $130 \mathrm{t}$ of $\mathrm{CO}_{2} \mathrm{e}$ depending on the fruit or vegetable and the destination market. The end-of-life stage contributed under $4 \%$ of the total emissions for all the scenarios while the contribution of transporting loaded boxes varied between $7 \%$ and $17 \%$. Predictably, scenarios with Germany as the destination had a greater CF.

It is important to note that the system boundaries of the analysis did not include the production of the transported vegetables and fruits. Nevertheless, previous studies have assessed the CF of this phase. For example, Pérez Neira et al. (2018) calculated an average $\mathrm{CF}$ of $136 \mathrm{t} \mathrm{CO}_{2} \mathrm{e}$ per $1000 \mathrm{t}$ for the production of tomatoes in the south of Spain on conventional farms. Considering this, the container system used to store and transport 1,000 t of product by road to France and Germany accounted for $36 \%$ and $37 \%$ of the total CF, respectively, for tomatoes transported in $600 \times 400 \times 90 \mathrm{~mm}^{3}$ boxes. A comparison between the same life cycle phases in other studies was not possible as the functional units and scope of the existing studies cited in the introduction 
are different, i.e., oranges were the products transported and the destination was to local markets instead of exports.

Biogenic $\mathrm{CO}_{2}$ was considered separately, as established following ISO 14067:2018.

Although it is not mandatory, $\mathrm{CO}_{2}$ emissions were also included due to land transformation and absorption. Figure 12 shows $\mathrm{CO}_{2}$ emissions due to each source.

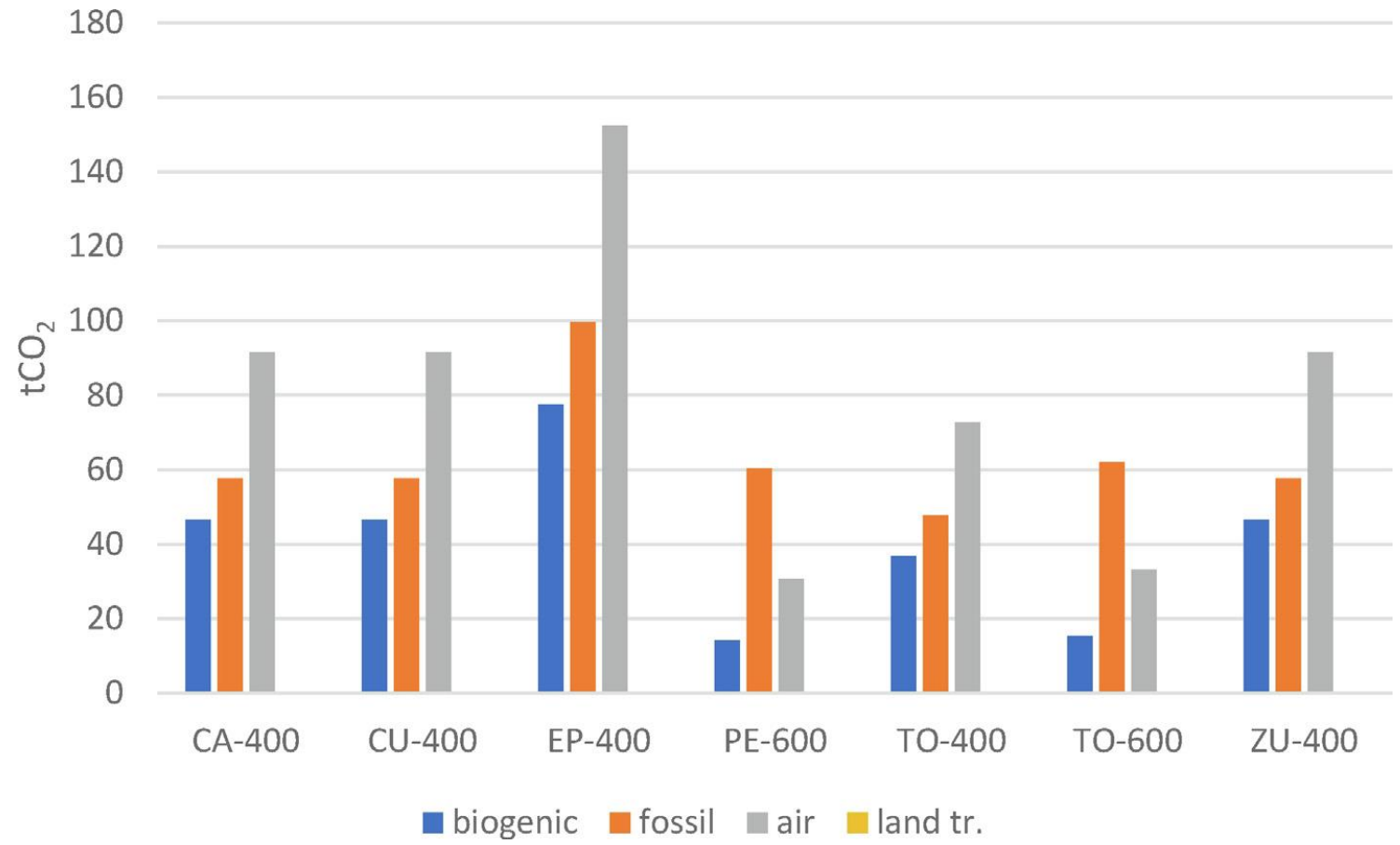

Fig. 12 a. $\mathrm{CO}_{2}$ emissions by origin for product systems destined for France (1,500 km).

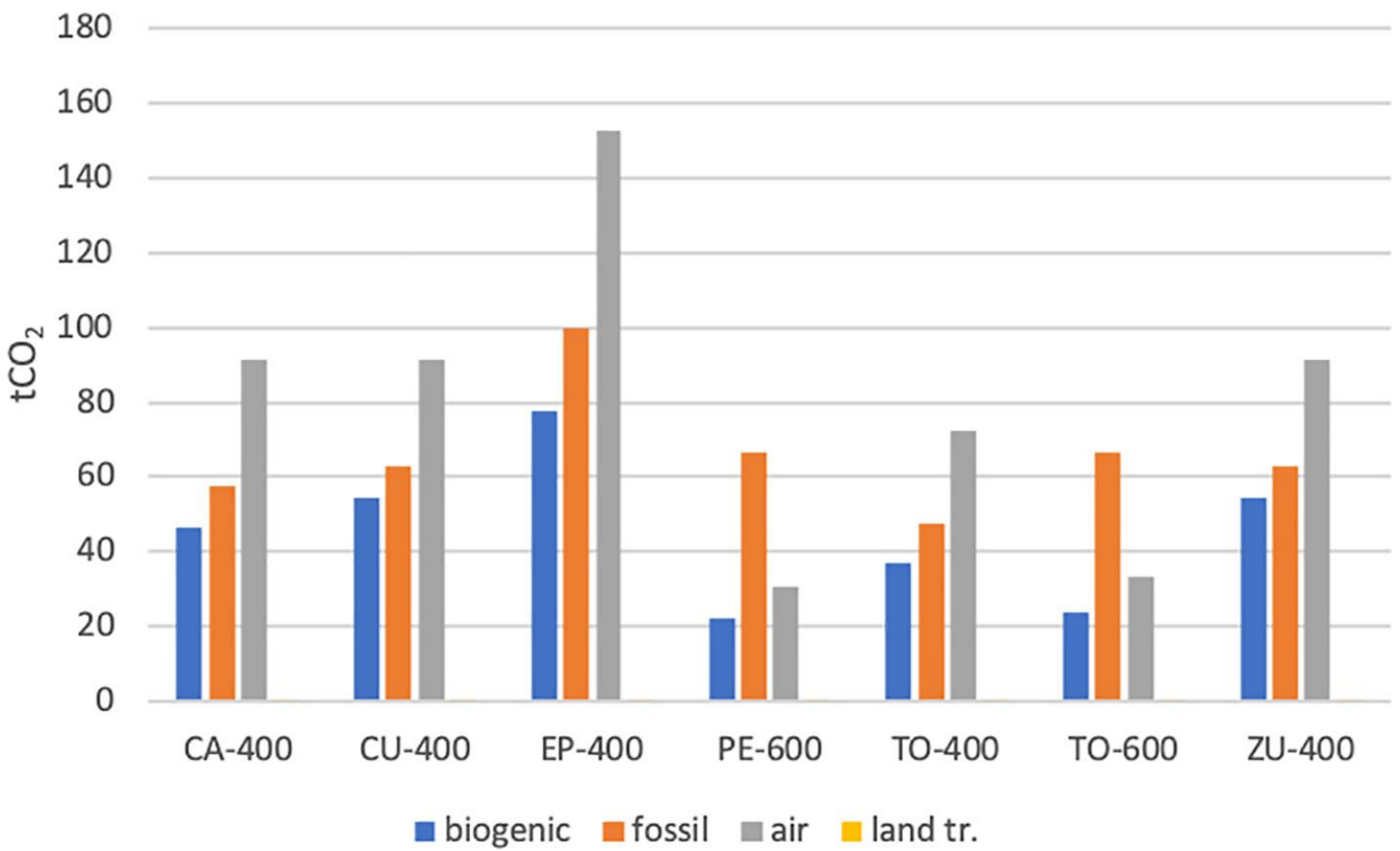

Fig. 12 b. $\mathrm{CO}_{2}$ emissions by origin for product systems destined for Germany $(2,500$ $\mathrm{km})$

Emissions due to biogenic $\mathrm{CO}_{2}$ were present in all the stages of the life cycle. Figure 13 shows the distribution of emissions by life cycle stage. A major proportion of the 
biogenic $\mathrm{CO}_{2}$ emissions was from the manufacturing stage due to the raw materials used and the paper fibers.

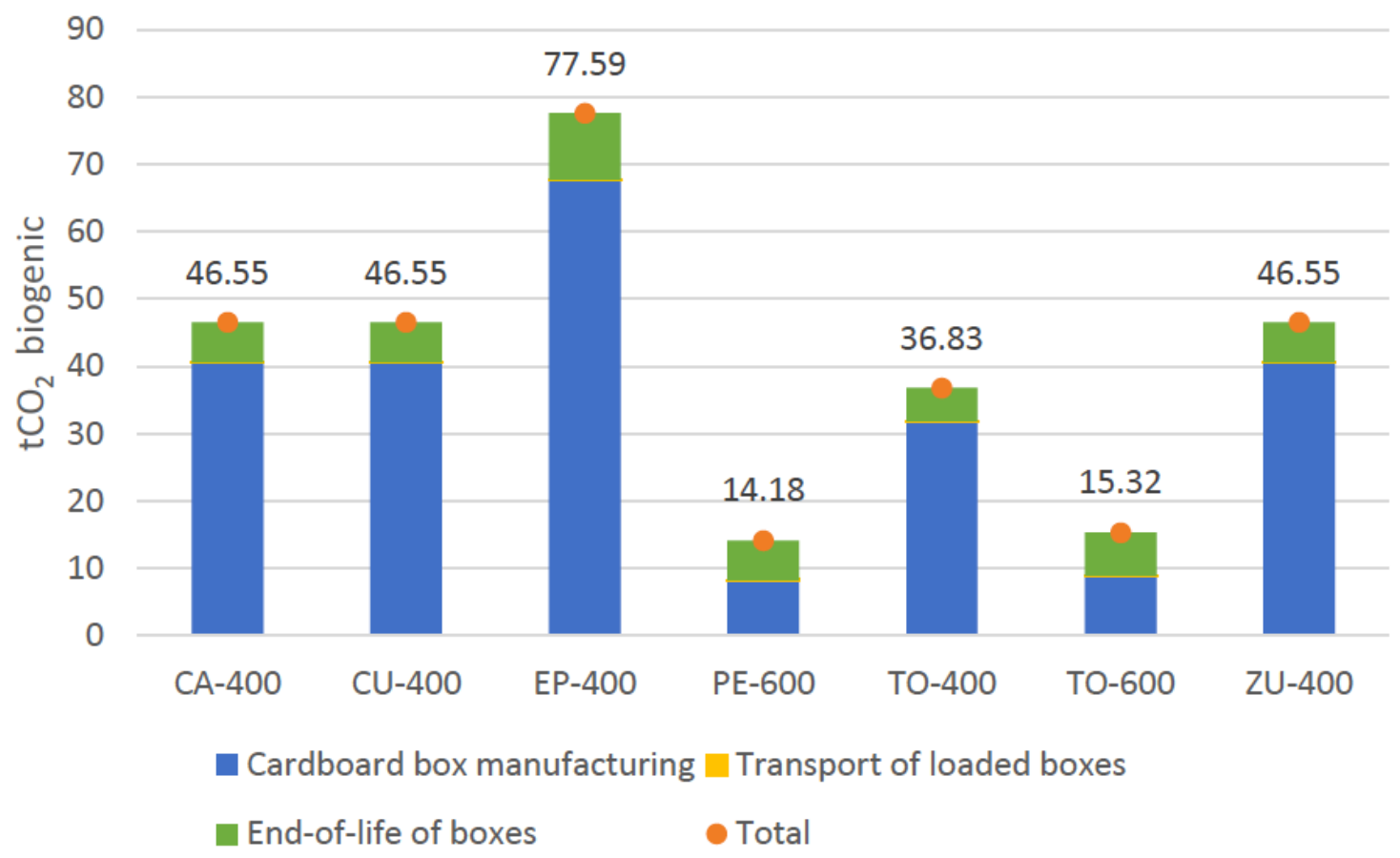

Fig. 13a. Biogenic $\mathrm{CO}_{2}$ for product systems destined for France $(1,500 \mathrm{~km})$.

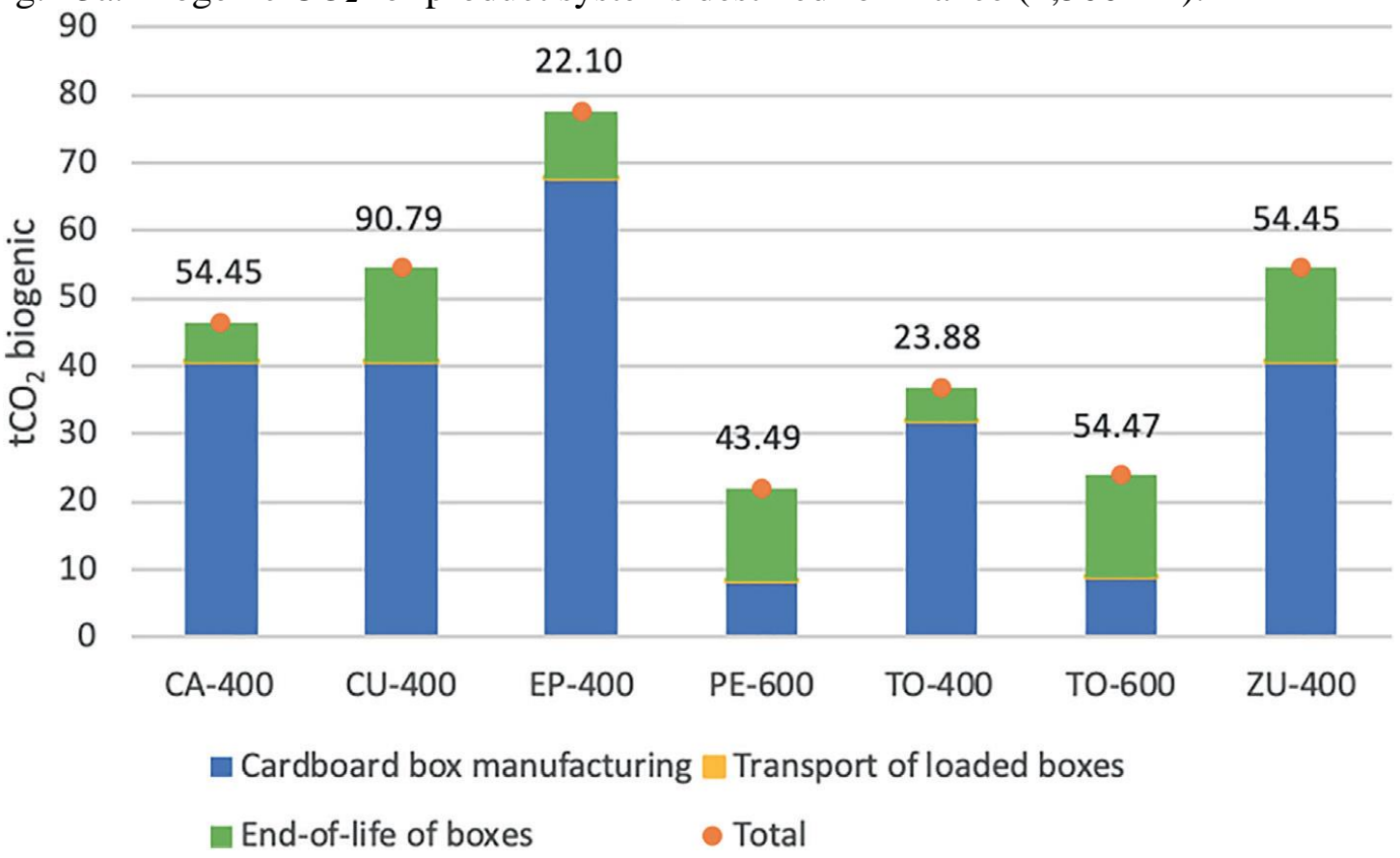

Fig. 13b. Biogenic $\mathrm{CO}_{2}$ for product systems destined for Germany $(2,500 \mathrm{~km})$.

Figure 14 shows the results of the sensitivity analysis of the distance for tomatoes transported in $600 \times 400 \times 90 \mathrm{~mm}^{3}$ boxes, the main product exported to these markets. For this analysis, the Netherlands was considered as a third destination. The results show a positive but non-linear relationship between distance and the $\mathrm{CF}$. 


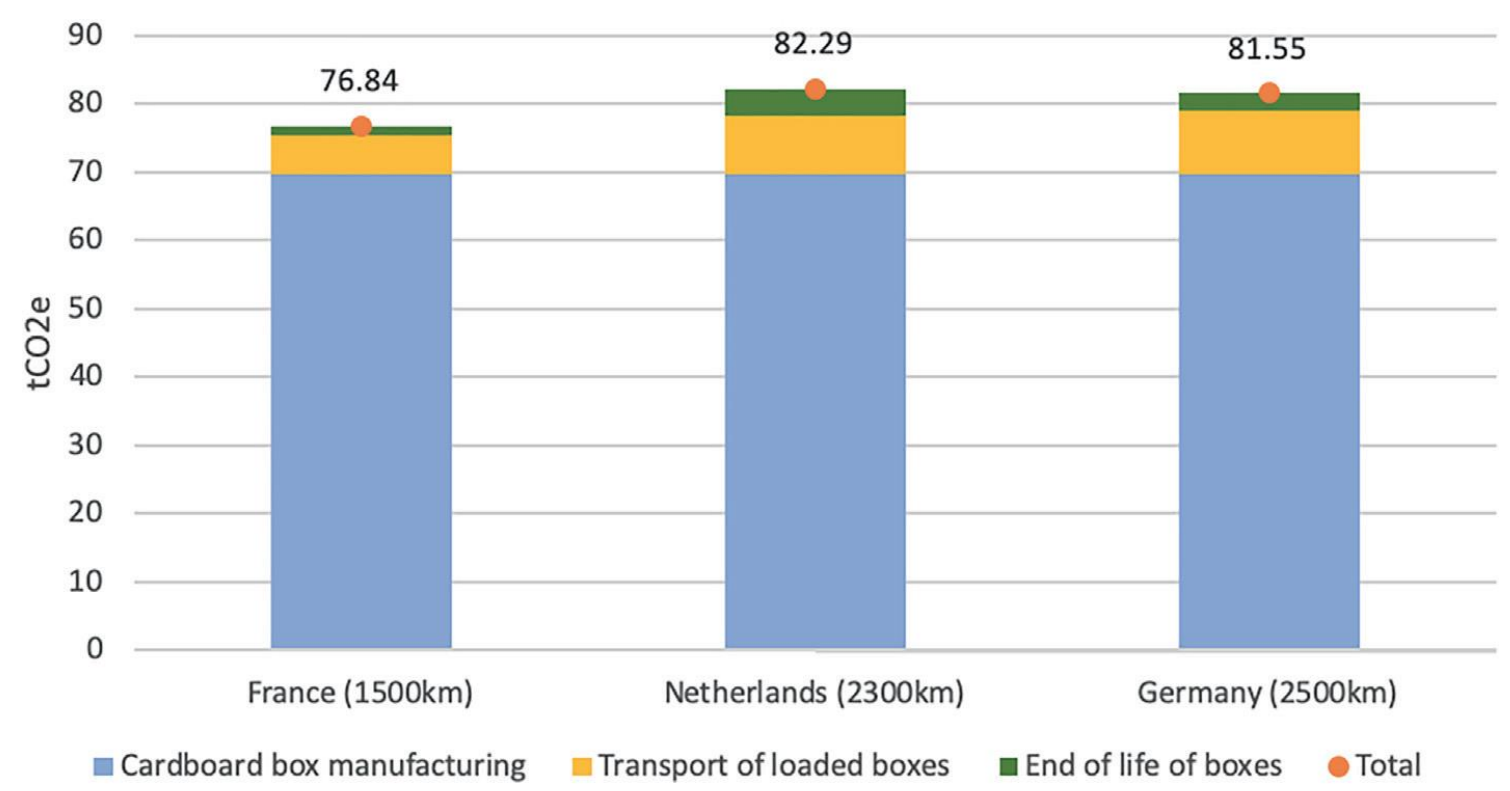

Fig. 14 Sensitivity analysis for the CF of product system TO-600 considering France $(1,500 \mathrm{~km})$, the Netherlands $(2,300 \mathrm{~km})$, and Germany $(2,500 \mathrm{~km})$.

Although distance had a significant influence on the $\mathrm{CF}$, the end-of-life phase can also lead to a large volume of emissions. The waste treatment processes, which defers from one country to another, also influenced the $\mathrm{CF}$ with respect to distance. Following the methodology and inventory analysis described, material recycling was assigned as a benefit for the manufacturing stage. However, incineration with energy recovery and landfill generated a direct contribution to the emissions during the end-of-life stage. The share of incineration for the Netherlands $(24.59 \%)$ was significantly higher than for France $(5.15 \%)$ and Germany $(0.03 \%)$ (see Table 11$)$.

\section{Conclusions}

The $\mathrm{CF}$ was found to be a useful environmental indicator to assess the impact of the target functional unit, defined as the container system to store and transport 1,000 t of product by road from the south of Spain to the dominant export markets of France and Germany.

Although all phases of the life cycle influenced the $\mathrm{CF}$, the transport distance and the end-of-life scenario- which depends on the destination country - were the key factors affecting emissions.

The further study of other types of fruit and vegetables such as citrus fruits and leafy vegetables could provide further information, particularly as their containers may be different owing to the characteristics of each product (i.e., more resistant and different shapes). Other destination markets with different end-of-life scenarios could also be considered to improve the available information on CFs.

\section{References}

ADEME (2000) Analyse du cycle de vie des caisses en bois, carton ondulé et plastic pour pommes (LCA of wooden boxes, cardboard boxes and plastic crates for apples). Agence de l'Environnement et de la Maîtrise de l'Energie. Retrived from: https://www.ademe.fr/sites/default/files/assets/documents/28246_acvs.pdf Retrieved March 30th, 2017. 
Albrecht, S., Brandstetter, P., Beck, T., Fullana-i-Palmer, P., Grönman, K., Baits, M., Deimling, S., Sandilands, J., Fischer, M., (2013) An extended life cycle analysis of packaging systems for fruit and vegetable transport in Europe. International Journal of Life Cycle Assessment, 18, p1549-p1567 https://doi.org/10.1007/s11367-013-0590-4 Atallah, S., Gómez, M., Björkman, T., (2014) Localization effects for a fresh vegetable product supply chain: Broccoli in the eastern United States. Food Policy, 49, p151 p159 https://doi.org/10.1016/j.foodpol.2014.07.005

Borsato, E., Tarolli, P., Marinello, F,. (2018) Sustainable patterns of main agricultural products combining different footprint parameters. Journal of Cleaner Production, 179, p357-p367 https://doi.org/10.1016/j.jclepro.2018.01.044

Bortolini, M., Faccio, M., Ferrari, M., Gamberi, M., Pilati, F., (2016) Fresh food sustainable distribution: cost, delivery time and carbon footprint three-objective optimization. Journal of Food Engineering, 174, p56- p67

https://doi.org/10.1016/j.jfoodeng.2015.11.014

British Standard Institute (2008) PAS 2050:2008 - specification for the assessment of the life cycle greenhouse gas emissions of goods and services. Available via http://www.bsigroup.com/en/Standards-and-Publications/Industry-

Sectors/Energy/PAS-2050/

Chonhenchob V, Singh SP (2003) A comparison of corrugated boxes and reusable plastic containers for mango distribution. Packaging Technology and Science, 16, p231p237 https://doi.org/10.1002/pts.630

Chonhenchob V, Singh SP (2005) Packaging performance comparison for distribution and export of papaya fruit. Packaging Technology and Science, 18, p125-p131 https://doi.org/10.1002/pts.681

Corrugated Packaging.

Del Borghi, A., Gallo, M., Strazza, C., Del Borghi, M., (2014) An evaluation of environmental sustainability in the food industry through life cycle assessment: the case study of tomato products supply chain. Journal of Cleaner Production, 78, 121-130. https://doi.org/10.1016/j.jclepro.2014.04.083

EMEP/EEA (2014). "Emission inventory guidebook 2013 update Sept 2014".

Europea de Estadística. http://ec.europa.eu/eurostat Retrieved March 30th, 2017

EUROSTAT (2017). "Transporte de mercancías por tipo de transporte en 2015".

Oficina

Federal Statistical Office (2013). "Population, families, living arrangements".

FEFCO (2015). "European Database for Corrugated Board Life Cycle Studies". FEFCO FEPEX (2017) Report: "Exportaciones por producto y por país. Federación Española de Asociaciones de Productores Exportadores de Frutas, Hortalizas, Flores y Plantas Vivas".

FEPEX (2017). "Exportaciones por producto y por país. Federación Española de Asociaciones de Productores Exportadores de Frutas, Hortalizas, Flores y Plantas Vivas". http://www.fepex.es/datos-del-sector/exportacion-importacion-española-frutashortalizas Retrieved March 30th, 2017.

Finkbeiner, M., (2009) Carbon footprinting - opportunities and threats. International Journal of Life Cycle Assessment, 14, p91 - 94 http://doi.org/10.1007/s11367-0090064-X

Forster P.; Ramaswamy V.; Artaxo P.; Berntsen T.; Betts R.; Fahey D.W.; Haywood J.; Lean J.; Lowe D.C.; Myhre G.; Nganga J.; Prinn R.; Raga G.; Schulz M. and Van Dorland R. (2007). Changes in Atmospheric Constituents and in Radiative Forcing. In: "Climate Change 2007: The Physical Science Basis. Contribution of Working Group I to the Fourth Assessment Report of the Intergovernmental Panel on Climate Change" 
[Solomon, S., D. Qin, M. Manning, Z. Chen, M. Marquis, K.B. Averyt, M.Tignor and H.L. Miller (eds.)]. Cambridge University Press, Cambridge, United Kingdom and New York, NY, USA.

http://carton-machines.es/6-die-cutting-stripping-machine.html Retrieved March 30th, 2017

Group Uniq (2019) Website http://www.grupouniq.com/ Retrieved May 10 $0^{\text {th }}, 2019$ IEA (2015). "Energy Policies of IEA Countries. Spain. 2015 Review". International Energy Agency. Paris.

IMO (2015). “Third IMO Greenhouse Gas Study 2014”. International Maritime Organization. London.

INSEE (2015). "Recensement de population. Population des communes les plus peuplées. 2013". https://www.insee.fr/fr/information/2008354 Retrieved March 30th, 2017

ISO (2006) ISO 14044:2006 environmental management-life cycle assessmentrequirements and guidelines. International Organization for Standardization, Geneva ISO (2018) ISO 14067:2018 greenhouse gases - Carbon footprint of products Requirements and guidelines for quantification and communication Kaab, A., Sharifi, M., Mobli, H., Nabavi-Pelesaraei, A., \& Chau, K. W. (2019). Combined life cycle assessment and artificial intelligence for prediction of output energy and environmental impacts of sugarcane production. Science of the Total Environment, 664, 1005-1019. https://doi.org/10.1016/j.scitotenv.2019.02.004 Kouchaki-Penchah, H., Nabavi-Pelesaraei, A., O'Dwyer, J., \& Sharifi, M. (2017). Environmental management of tea production using joint of life cycle assessment and data envelopment analysis approaches. Environmental Progress \& Sustainable Energy, 36(4), 1116-1122. https://doi.org/10.1002/ep.12550

Levi M, Cortesi S, Vezzoli C, Salvia G (2011) A comparative life cycle assessment of disposable and reusable packaging for the distribution of Italian fruit and vegetables. Packaging Technology and Science, 24, p387-p400, https://doi.org/10.1002/pts.946 MAIKWA (2017). Manufacturers of machines for cardboard production. Manfredi, M., Vignali, G., (2014) Life cycle assessment of a packaged tomato puree: a comparison of environmental impacts produced by different life cycle phases. Journal of Cleaner Production, 73, p275-p284 https://doi.org/10.1016/j.jclepro.2013.10.010 Nabavi-Pelesaraei, A., Kouchaki-Penchah, H., \& Amid, S. (2014). Modeling and optimization of $\mathrm{CO} 2$ emissions for tangerine production using artificial neural networks and data envelopment analysis. International Journal of Biosciences, 4(7), 148-158. Nabavi-Pelesaraei, A., Bayat, R., Hosseinzadeh-Bandbafha, H., Afrasyabi, H., \& Berrada, A. (2017a). Prognostication of energy use and environmental impacts for recycle system of municipal solid waste management. Journal of Cleaner Production, 154, 602-613 https://doi.org/10.1016/j.jclepro.2017.04.033

Nabavi-Pelesaraei, A., Bayat, R., Hosseinzadeh-Bandbafha, H., Afrasyabi, H., \& Chau, K. W. (2017b). Modeling of energy consumption and environmental life cycle assessment for incineration and landfill systems of municipal solid waste managementA case study in Tehran Metropolis of Iran. Journal of Cleaner production, 148, 427-440. https://doi.org/10.1016/i.jclepro.2017.01.172

Neugebauer, S., Martinez-Blanco, J., Scheumann, R.,Finkbeiner., M. (2015) Enhancing the practical implementation of life cycle sustainability assessment e proposal of a Tiered approach. Journal of Cleaner Production, 102, p165 - p176 https://doi.org/10.1016/j.jclepro.2015.04.053 
Organization for Standardization (2013) ISO/TS 14067- 2003Greenhouse gasescarbon footprint of products - requirements and guidelines for quantification and communication. International Organization for Standardization (ISO), Geneva

Parajuli, R., Thoma, G., Matlock, M.D. (2019) Environmental sustainability of fruit and vegetable production supply chains in the face of climate change: A review, Science of The Total Environment, 650, Part 2, p2863-p2879,

https://doi.org/10.1016/j.scitotenv.2018.10.019

Pattara, C., Salomone, R., Cichelli, A., (2016) Carbon footprint of extra virgin olive oil: a comparative and driver analysis of different production processes in Centre Italy.

Journal of Cleaner Production, 127, p533-p547

https://doi.org/10.1016/i.jclepro.2016.03.152

Payen, S., Basset-Mens, C., Perret, S., (2015) LCA of local and imported tomato: an energyand water trade-off. Journal of Cleaner Production 87, 139-148.

https://doi.org/10.1016/i.jclepro.2014.10.007

Pérez Neira, D., Soler Montiel, M., Delgado Cabeza, M., Reigada, A. (2018) Energy use and carbon footprint of the tomato production in heated multi-tunnel greenhouses in Almeria within an exporting agri-food system context. Science of the Total

Environment, 628 - 629, p1627 - p1636 https://doi.org/10.1016/j.scitotenv.2018.02.127

Pérez-Neira, D., Grollmus-Venegas, A. (2018) Life-cycle energy assessment and carbon footprint of peri-urban horticulture. A comparative case study of local food systems in Spain. Landscape and Urban Planning, 172, p60 - p68

https://doi.org/10.1016/j.landurbplan.2018.01.001

Pre-sustainability (2019). http://www.pre-sustainability.com/simapro-lca-software. (accessed 15.04.2019.)

Qasemi-Kordkheili, P., \& Nabavi-Pelesaraei, A. (2014). Optimization of energy required and potential of greenhouse gas emissions reductions for nectarine production using data envelopment analysis approach. International Journal of Energy and Environment, 5(2), 207-219.

River-Méndez, Y. D., Rodríguez, D. T., Romero, H. M. (2017) Carbon footprint of the production of oil palm (Elaeis guineensis) fresh fruit bunches in Colombia, Jorunal of Cleaner Production, 149, p743 - p750 https://doi.org/10.1016/j.jclepro.2017.02.149 Röös, E., Karlsson, H., (2013) Effect of eating seasonal on the carbon footprint of Swedish vegetable consumption. Journal of Cleaner Production, 59, p63-p73 https://doi.org/10.1016/j.jclepro.2013.06.035

Sabzevari, A., Kouchaki-Penchah, H., \& Nabavi-Pelesaraei, A. (2015). Investigation of life cycle assessment of hazelnut production in Guilan province of IR Iran based on orchards size levels. Biological Forum, 7(1), 807-813

Sanyé-Mengual, E., Cerón-Palma, I., Olvier-Solà, J., Montero, J.I., Rieradevall, J. (2013) Environmental analysis of the logistics of agricultural products from roof top greenhouses in Mediterranean urban areas. Journal of Science Food Agriculture, 93, p100 - p109 http://doi.org/10.1002/jsfa.5736

Shabanzadeh-Khoshrody, M., Azadi, H., Khajooeipour, A., \& Nabavi-Pelesaraei, A. (2016). Analytical investigation of the effects of dam construction on the productivity and efficiency of farmers. Journal of Cleaner Production, 135, 549-557.

https://doi.org/10.1016/j.jclepro.2016.06.145

Sim, S., Barry, M., Clift, R., Cowell, S.J., (2007) The relative importance of transport in determining an appropriate sustainability strategy for food sourcing. International

Journal of Life Cycle Assessment, 12, p422-p431

http://dx.doi.org/10.1065/lca2006.07.259 
Singh SP, Chonhenchob V, Singh J (2006) Life cycle inventory and analysis of reusable plastic containers and display-ready corrugated containers used for packaging fresh fruits and vegetables. Packaging Technology and Science, 19, p279-p293 https://doi.org/10.1002/pts.731

Soode, E., Lampert, P., Weber-Bñaschke, G., Richter, K., (2015) Carbon footprints of the horticultural products strawberries, asparagus, roses and orchids in Germany. Journal of Cleaner Production, 87, p-168-p179

https://doi.org/10.1016/i.jclepro.2014.09.035

Statistical Yearbook, Germany, 2012. Wiesbaden.

Statistics Netherlands (2016). http://statline.cbs.nl/Statweb Retrieved March 30th, 2017

Vía Michelín (2017) Distance between cities by road https://www.viamichelin.es/

Retrieved March 30th, 2017

Wernet, G.; Bauer, C.; Steubing, B.; Reinhard, J.; Moreno-Ruiz, E.; and Weidema, B. (2016). The ecoinvent database version 3 (part I): overview and methodology. International Journal of Life Cycle Assessment, 21, p1218-p1230.

https://doi.org/10.1007/s11367-016-1087-8

\section{Acknowledgements}

The authors wish to thank to the UNIQ Agricultural Quality Seal of the Spanish Corrugated Carboard Manufacturers Association (AFCO) and the Instituto de Producci_on Sostenible (IPS, Institute for Sustainable Production) for their support providing valuable information for this study. 